\title{
Victims of Involuntary Disappearance: An Overview of International Law
}

Shabina Arfat* and Beauty Banday ${ }^{\dagger}$

\begin{abstract}
Victims of involuntary disappearance suffer from physical/mental injury, emotional suffering, economic loss resulting in substantial impairment of fundamental rights, through acts or omissions that constitute gross violations of international human rights law, or humanitarian law. It also reveals that even the rights of immediate family of a victim of involuntary disappearance are violated. Unlike olden times, the rights of the sufferers of involuntary disappearance are now well protected under various international instruments. This paper throws light on acts of involuntary disappearance, as one of the worst case of violation of human rights.
\end{abstract}

Keywords: Armed Conflict; Human Rights; Humanitarian Law; International Instruments; Involuntary Disappearance

\section{Introduction}

The crime of involuntary disappearance or enforced disappearance was invented by Adolf Hitler in his Nacht und Nebel Erlass (Night

* PhD Scholar, Faculty of Law, University of Kashmir, Srinagar; arfatshab9@gmail.com

† Senior Assistant Professor, Faculty of Law, University of Kashmir, Srinagar. 
and Fog Decree) issued on 7 December 1941.1 The Third Reich's Night and Fog program represents the earliest use of enforced disappearance as an explicit state policy. A memorandum from the High Command of the German Armed Forces explained the basic elements of this counter insurgency program:

In all other cases, the prisoners are in the future to be transported to Germany secretly, and further dealings with the offences will take place here; these measures will have a deterrent effect because:
A. the prisoner will vanish without leaving a trace,
B. no information may be given as to their whereabouts or their fate. ${ }^{2}$

Since that date, thousands of persons have been the victims of this crime. Sadly, the commission of this crime saw resurgence in Latin America in the 1950s and then it spread around the world. An enforced disappearance occurs when:

Persons are arrested, detained or abducted against their will or otherwise deprived of their liberty by officials of different branches or levels of government, or by organised groups or private individuals acting on behalf of, or with the support, direct or indirect, consent or acquiescence of the government, followed by a refusal to disclose the fate or whereabouts of the persons concerned or a refusal to

\footnotetext{
${ }^{1}$ Maureen R. Berman \& Roger S. Clark, State Terrorism: Disappearances, 13 RuTGERS L.J. 531 (1982); See, Trials of War Criminals Before The Nuremberg Military Tribunals Under Control Council Law, No. 10 at 1042, October 1946 April 1949, http://www.loc.gov/rr/frd/Military_Law/NTs_warcriminals.html\#top (last visited Feb. 3, 2013).

2 Memorandum from the High Command of the Armed Forces to Office Foreign Countries, Counter Intel./Dep't Abwehr, Feb. 2, 1942, translated in 7 OfFice of UNITED STATES CHIEF OF COUNSEl For THE PROSECUTION OF AXIS CRIMINALITY, NAZI CONSPIRACY AND AGGRESSION 871, 872 (1946); Memorandum from the Chief of the High Command of the Armed Forces on Prosecution of Offenses Committed Within the Occupied Countries Against the German State or the Occupying Powers, Dec. 12, 1941, translated in 7 OFFICE OF THE UNITED STATES CHIEF OF COUNSEL 873.
} 
acknowledge the deprivation of their liberty, which places such persons outside the protection of the law. ${ }^{3}$

'Enforced disappearance of person' means:

the arrest, detention or abduction of persons by, or with the authorization, support or acquiescence of, a state or a political organization, followed by a refusal to acknowledge that deprivation of freedom or to give information on the fate or whereabouts of those persons, with the intention of removing them from the protection of the law for a prolonged period of time. ${ }^{4}$

The definition of missing persons that the International Committee of Red Cross uses is:

A missing person is a person whose whereabouts are unknown to his/her relatives and/or who, on the basis of reliable information, has been reported missing in accordance with the national legislation in connection with an international or non international armed conflict, a situation of internal violence or disturbances, natural catastrophes or any other situation that may require the intervention of a competent state authority.

\section{Protection of Victims of Involuntary Disappearance}

In the conventional human rights conception, the international crime of enforced disappearance evolved out of human rights instruments and declarations created in response to disappearances perpetrated in Latin America during the 1960s, 1970s,

3 Declaration on the Protection of All Persons from Enforced Disappearance art. 7(2)(i), G. A. Res. 47/133, (Dec. 18, 1992), available at http://www2.ohchr.org/english/law/disappearance.htm (last visited Feb. 3, 2013).

${ }^{4}$ Rome Statute of the International Criminal Court, 2187 U.N.T.S. 90 (July 17, 1998), available at http://untreaty.un.org/cod/icc/statute/ romefra.htm (last visited Feb. 3, 2013). 
and1980s. ${ }^{5}$ According to this account, the key milestones in the criminalisation of the enforced disappearances are the 1992 Declaration on the Protection of All Persons from Enforced Disappearance, ${ }^{6}$ the 1994 Inter American Convention on Forced Disappearance of Persons, 7 and the 2006 International Convention for the Protection of All Persons from Enforced Disappearance. ${ }^{8}$

Having been removed from the protective precinct of the law and "disappeared" from society, victims of enforced disappearance are in fact deprived of all their rights and are at the mercy of their captors. Some of the rights that enforced disappearances regularly violate are:

- Right to recognition as a person before the law;

- Right to liberty and security of the person;

- Right not to be subjected to torture and other cruel, inhuman or degrading treatment or punishment;

- Right to life, when the disappeared person is killed;

- Right to an identity;

- Right to a fair trial and to judicial guarantees;

- Right to an effective remedy, including reparation and compensation;

- Right to know the truth regarding the circumstances of a disappearance;

- Right to protection and assistance to the family;

\footnotetext{
${ }^{5}$ Machteld Boot, Nullum Crimen Sine Lege And The Subject Matter JURISDICTION OF THE INTERNATIONAL CRIMINAL COURT: GENOCIDE, CRIMES AGAinst HuMANITY AND WAR CRIMES 526-27 (2002); See STEVEN R. RATNER, JASON S. ABRAMS AND JAMES BISCHOFF, ACCOUNTABILITY FOR Human RightS Atrocities in INTERNATIONAL LAW: BEYOND THE NUREMBERG LEGACY 128-29 (3 ${ }^{\text {rd }}$ ed. 2009).

${ }^{6}$ G. A. Res. 47/133, supra note 3.

7 Inter-American Convention on Forced Disappearance of Persons art. 3, 33 I.L.M. 1429 (1994), available at http://www1.umn.edu/humanrts/ instree/forceddisapp.html (last visited Feb. 3, 2013).

8 International Convention for the Protection of All Persons from Enforced Disappearance, G.A. Res. A/RES/61/177, U.N. Doc. A/HRC/RES/ 2006/ 1 (Dec. 20, 2006).
} 
- Right to an adequate standard of living;

- Right to health;

- Right to education.

Enforced disappearance remains one of the heinous human rights violations. As stated in Article 1 of the Declaration on the Protection of all Persons from Enforced Disappearance:

Any act of enforced disappearance places the person subjected thereto outside the protection of the law and inflicts severe suffering on them and their families. It constitutes a violation of the rules of international law guaranteeing, inter alia, the right to recognition as a person before the law, the right to liberty and security of the person and the right not to be subjected to torture and other cruel, inhuman or degrading treatment or punishment. It also violates or constitutes a grave threat to the right to life. ${ }^{9}$

Article 24 of the International Convention for the Protection of All Persons from Enforced Disappearance, in relevant part reads: For the purposes of this Convention, 'victim' means the disappeared person and any individual who has suffered harm as the direct result of an enforced disappearance.

A person may be considered a victim, under this Declaration, regardless 0 of whether the perpetrator is identified, apprehended, prosecuted or convicted and regardless of the familial relationship between the perpetrator and the victim. The term 'victim' also includes, where appropriate, the immediate family or dependants of the direct victim and persons who have suffered harm in intervening to assist victims in distress or to prevent victimization. ${ }^{10}$

Victims are persons who individually or collectively suffered harm, including physical or mental injury, emotional suffering, economic loss or substantial impairment of their fundamental rights, through

9 Amnesty Int'1, No Impunity for Enforced Disappearances (2011), available at http:/ / amnesty.hr/wp/wp-content/uploads/2012/08/No-impunity-forenforced-disappearances.pdf (last visited Feb. 3, 2012).

10 U.N. Declaration of Basic Principles of Justice for Victims of Crime and Abuse of Power Principle 2, U.N. Doc. A/RES/40/34 (Nov. 29, 1989). 
acts or omissions that constitute gross violations of international human rights law, or serious violations of international humanitarian law. Where appropriate, and in accordance with domestic law, the term 'victim' also includes the immediate family or dependants of the direct victim and persons who have suffered harm in intervening to assist victims in distress or to prevent victimization. ${ }^{11}$

The families and friends of the victims experience mental anguish, because they have no knowledge of the victim's whereabouts. Even if they did not know where the victim is being held, they alternate between hope and despair, wondering and waiting, sometimes for years, for news that may never come. The family's distress is frequently compounded by the material consequences of the disappearance. The disappeared person is often the family's main breadwinner. The emotional upheaval is thus exacerbated by material deprivation, made more acute by the costs incurred should they decide to undertake a search. In some cases, national legislation may make it impossible to draw a pension or receive other means of support in the absence of a death certificate.

Economic and social marginalization is frequently the result. The serious economic hardships which usually accompany a disappearance are most often borne by women, and it is women who are most often at the forefront of the struggle to resolve the disappearance of family members. In this capacity they may suffer intimidation, persecution and reprisals. When women are themselves direct victims of disappearance, they become particularly vulnerable to sexual and other forms of violence. Children can also be victims, both directly and indirectly. The disappearance of a child is a clear contravention of a number of provisions of the United Nations Convention on the Rights of the Child, 1989 including the right to a personal identity. The loss of a

11 U.N. Basic Principles and Guidelines on the Right to a Remedy and Reparations for Victims of Gross Violations of International Human Rights Law and Serious Violations of International Humanitarian Law Principle 8 and 9, G. A. Res. 60/147 (Dec.16, 2005), available at http:// www2.ohchr.org/english/law/remedy.htm (last visited Feb. 3, 2012). 
parent through disappearance is also a serious violation of a child's human rights.

The victims of acts of enforced disappearance and their family shall obtain redress and shall have the right to adequate compensation, including the means for as complete rehabilitation as possible. In the event of the death of the victim as a result of an act of enforced disappearance, their dependants shall also be entitled to compensation. ${ }^{12}$ States shall prevent and suppress the abduction of children of parents subjected to enforced disappearance and of children born during their mother's enforced disappearance, and shall devote their efforts to the search for and identification of such children and to the restitution of the children to their families of origin. ${ }^{13}$

Post World War II instruments continue to emphasize the protection of the family during armed conflict. Article 27 of the Fourth Geneva Convention, 1949 provides that "protected persons are entitled, in all circumstances, to respect for their persons, their honour, and their family rights." 14 As the Official International Committee of the Red Cross (hereinafter referred to as "ICRC") Commentary on the Geneva Conventions 1949 notes, Article 27, like Article 46 of the Hague Convention 1907 from which it is derived, "is intended to safeguard the marriage ties and that community of parents and children which constitutes a family, the natural and fundamental group unit of society." 15 The commentary

12 G. A. Res. 47/133, supra note 3 art. 19.

13 G. A. Res. 47/133, supra note 3 art. 20; United Nations: General Assembly Resolution and Declaration on the Protection of All Persons from Enforced Disappearance, 1993, 3(3) I.L.M. 903-910, available at http://www.jstor.org/stable/20693812 (last visited Sep. 8, 2012).

14 Geneva Convention (IV) relative to the Protection of Civilian Persons in Time of War art. 27, 75 U.N.T.S. 287 (Oct. 21, 1950), available at http:/ / www.icrc.org/ihl.nsf/FULL/380?OpenDocument (last visited Feb. 3, 2013).

15 Oscar Uhler, Henri Coursier, COMMEntary ON The Geneva Conventions of 12 August 1949: Geneva Convention Relative To The Protection Of Civilian Persons In Time Of War 202 (Jean S. Pictet et al. eds., 1958). 
notes that the Fourth Geneva Convention, 1949 contains numerous other provisions protecting family rights, including Article 82, which provides that members of the same family should be lodged together in the same place of internment. Articles 25 and 26 oblige the parties to facilitate familial correspondence and the reunification of families. The protection of family rights in postWorld War II instruments, such as Article 27 of the Fourth Geneva Convention, 1949 is especially important, as violations of these provisions with respect to protected persons constitute grave breaches and carry individual criminal liability. Article 147 defines 'inhuman treatment' as a grave breach of the Convention. The ICRC commentary notes that although inhuman treatment is rather difficult to define, violations of Article 27 would constitute inhuman treatment. By inhuman treatment the convention does not mean only physical injury or injury to health. Certain measures, for example, which might cut the civilian internees off completely from the outside world and in particular from their families, could conceivably, be considered as inhuman treatment.

The grave breach provision of the Fourth Geneva Convention, 1949 protects the family rights of civilians in the hands of an occupying power or party to a conflict of which they are not nationals. ${ }^{16}$ The International Criminal Tribunal for the Former Yugoslavia (hereinafter referred to as "ICTY") has held that the convention is applicable to mixed international and non-international conflicts, and that a person may be protected under the grave breach provision of the Convention, even if that individual has the same legal nationality of an occupying power. ${ }^{17}$

Additional Protocol I protects with criminal sanctions the family rights of all civilians, not only those in the control of another state. Furthermore, Additional Protocol I specifies in greater detail than the Geneva, 1949 or Hague Conventions, the protections which are

1675 U.N.T.S. 287, supra note 14 art. 4.

17 Prosecutor v. Tadić, Case No. IT-94-1-I, Judgment of the Appeals Chamber, 『 164-66 (July 15, 1999). 
to be provided for families during international armed conflicts. ${ }^{18}$ It recognizes as a general principle "the right of families to know the fate of their relatives."19 Parties are obliged to facilitate and, if necessary, carry out search activities and convey information regarding individuals reported missing during the conflict. ${ }^{20}$ The parties are also obligated to facilitate the return of the remains of deceased persons. ${ }^{21}$ Under Additional Protocol I, grave breaches of the Geneva Convention 'shall be regarded as war crimes.'22 International humanitarian law also protects the family in non international conflict. Common Article 3 provides that noncombatants shall in all circumstances be treated humanely and prohibits cruel treatment. ${ }^{23}$ Additional Protocol II expands upon Common Article 3's protections, prohibiting violence to mental well-being, as well as 'cruel treatment' and 'acts of terrorism.'24

In the Cyprus case ${ }^{25}$ in 2001, the European Court of Human Rights stated:

the court recalls that the question whether a family member of a 'disappeared person' is a victim of treatment contrary to Article (3) $)^{26}$ will depend on the existence of special factors

18 Protocol Additional to the Geneva Conventions of 12 August 1949, and relating to the Protection of Victims of International Armed Conflicts (Protocol I), 1125 U.N.T.S. 3 (June 8, 1977).

19 Id. at art. 32.

$20 \mathrm{Id}$. at art. 33.

21 Id. at art. 34 .

${ }^{22} \mathrm{Id}$. at art. 85(5).

2375 U.N.T.S. 287 , supra note 14.

24 Protocol Additional to the Geneva Convention of 12 August 1949, and Relating to the Protection of Victims of International Armed Conflicts art. 4(3)(b), 1125 U.N.T.S. 609 (Jun. 8, 1977).

25 Cyprus v. Turkey, 25781/94, Eur. Ct. H.R., § 156 (May 10, 2001).

26 European Convention for the Protection of Human Rights and Fundamental Freedoms, E.T.S. 5 (Nov. 4, 1950), available at http:/ / www.echr.coe.int/NR/rdonlyres/D5CC24A7-DC13-4318-B4575C9014916D7A/0/Convention_ENG.pdf (last visited Feb. 3, 2013). 
which give the suffering of the person concerned a dimension and character distinct from the emotional distress which may be regarded as inevitably caused to relatives of a victim of a serious human rights violation. Relevant elements will include the proximity of the family tie. In that context, a certain weight will attach to the parent child bond, the particular circumstances of the relationship, the extent to which the family member witnessed the events in question, the involvement of the family member in the attempts to obtain information about the disappeared person and the way in which the authorities responded to those enquiries.

The court further recalled that the essence of such a violation does not so much lie in the fact of the 'disappearance of the family member but rather in the authorities' reactions and attitudes to the situation when it is brought to their attention. It is especially in respect of the latter that a relative may claim directly to be a victim of the authorities' conduct. ${ }^{27}$

If the male member of the family disappears, women are those who most often bear the economic, social and psychological consequences. Since women are also at the forefront of the struggle to resolve the disappearances of members of their families, in all probability they are also likely to be at the forefront in the victims' interaction with your community. Full focus on women and children in future proceedings, including through the reporting process should be encouraged. 28

Irrespective of any legal proceedings, victims and their families have the right to know the truth about the circumstances in which violations took place and, in the event of death or disappearance,

27 Cyprus v. Turkey, 25781/94, Eur. Ct. H.R., § 156 (May 10, 2001).

28 Navi Pillay, High Commissioner, United Nations, Opening Address for Human Rights to the Committee on Enforced Disappearances - Second Session, Geneva (Mar. 26, 2012), available at http://www.ohchr.org/en/ NewsEvents/Pages/DisplayNews.aspx?NewsID=12014\&LangID=e (last visited Feb. 3, 2012). 
the victims' fate. ${ }^{29}$ Moreover, victims and their representatives should be entitled to seek and obtain information on the causes leading to their victimization and on the causes and conditions pertaining to the gross violations of international human rights law and serious violations of International Humanitarian Law and to learn the truth in regard to these violations. ${ }^{30}$

In its judgment in Prosecutor v. Kordic \& Cerkez $z^{31}$ the Appeals Chamber of the International Criminal Tribunal for the former Yugoslavia, stated that "the unfortunate legacy of wars shows that until today many perpetrators believe that violations of binding international norms can be lawfully committed, because they are fighting for a just cause. Those people have to understand that international law is applicable to everybody, in particular during times of war." Thus, the sentences rendered by the International Tribunal have to demonstrate the fallacy of the old Roman principle of inter arma silent leges (amid the arms of war the laws are silent) in relation to the crimes under the International Tribunal's jurisdiction. ${ }^{32}$

The Working Group on Enforced or Involuntary Disappearances (hereinafter referred to as "UNWGEID") was established by the UN Commission on Human Rights in 1980 with the objective to investigate questions relating to enforced or involuntary disappearances. Initially, the UNWGEID had a humanitarian mandate. In 1992 its functions were broadened by the adoption of the Declaration for the Protection of All Persons from Enforced

${ }^{29}$ U.N. Updated Set of Principles for the Protection and Promotion of Human Rights through Action to Combat Impunity Principle 4 and 8, U.N. Doc. E/CN.4/2005/102/Add.1 (Feb. 8, 2005).

${ }^{30}$ G. A. Res. 60/147, supra note 11 Principle 24.

${ }^{31}$ Prosecutor v. Kordic \& Cerkez, Case No. IT-95-14/2-A, ICTY, (Dec. 17, 2004).

32 Id. at 9108 ; see Amnesty Int'l, In International Commission of Jurists and Redress Draft Guidelines of the Committee of Ministers of the Council of Europe on Eradicating Impunity for Serious Human Rights Violations: Reference Texts Suggestions for additional references, (Sep., 2010), available at http:// www.redress.org/downloads/publications/Impunityguidelines1 30910final.pdf (last visited Feb. 3, 2013). 
Disappearances. The Human Rights Commission assigned a monitoring function to the working group and as a result, the UNWGEID can today be considered a monitoring body. The primary objective of the UNWGEID is to ensure that cases of enforced disappearances are investigated and clarified by the domestic authorities. However, the working group does not by itself investigate individual cases, neither does it formulate judgments, order sanction, or carry out exhumations. The UNWGEID can be best described as a channel of communication between Ofamilies and their governments. The UNWGEID accepts cases from any country in the word. Further, it is not necessary to exhaust domestic procedures before submitting the case to the working group. Cases of disappearances can be submitted by relatives of disappeared persons or by organisations acting on their behalf.

The Human Rights Committee has consolidated its views that an enforced disappearance must be remedied by:

- Investigating to establish the fate of the disappeared person;

- Securing the release of the disappeared person if it is still possible;

- Bringing to justice any persons found to be responsible for the disappearance (purely disciplinary or administrative remedies cannot constitute adequate remedies);

- Paying compensation to the victim or to the family for any injury they suffered;

- Ensuring that similar violations do not occur in the future.

The right to obtain reparation referred to covers material and moral damages and, where appropriate, other forms of reparation ${ }^{33}$ such as:

[1] restitution;

[2] rehabilitation;

[3] satisfaction, including restoration of dignity and reputation;

[4] guarantees of non repetition.

${ }^{33}$ G. A. Res. A/RES/61/177, supra note 8 art. 24. 
The UN Convention on the Rights of the Child, 1989, Article 39 states that "States Parties shall take all appropriate measures to promote physical and psychological recovery and social reintegration of a child victim." According to the UN Basic Principles and Guidelines, the notion of 'rehabilitation' owed to victims includes medical and psychological rehabilitation. ${ }^{34}$

Declaration on the Protection of All Persons from Enforced Disappearance establishes that "the victims of acts of enforced disappearance and their family shall obtain redress and shall have the right to adequate compensation, including the means for as complete rehabilitation as possible".

A state is bound to comply with the rules set in the laws of that country itself. National laws usually need to be adopted by the legislative power. Often the most fundamental rights that a state has to guarantee its citizens are written in the Constitution of a country. In order to be respected, laws need to be enforced. Therefore states have law enforcement services (the police and other services) pertaining to the executive power. Each country also has a national judicial system (national courts or tribunals, constitutional courts) to give the proper interpretations of the laws and to settle disputes. This judicial power should be independent from the executive power and counterbalance it. However, in many countries where enforced disappearances take place, the executive power is actually committing enforced disappearances instead of protecting the rights of persons and the judicial power is often fully dominated by this branch of power. There are some unwritten obligations that are considered valid at all times and for all states, even without states having formally accepted them. These obligations are derived from universally accepted norms. There are a few incontestable norms (also called jus cogens). For example all states must: refrain from using torture under all circumstances; avoid genocide at all costs; suppress and prevent slavery. There are also a few obligations that originate in the common practice (the custom) in a country or between countries. These norms (also called customary law) are considered to be valid even if not written down, just because custom established them. The right not to be

${ }^{34}$ G. A. Res. 60/147, supra note 11. 
disappeared (creating the obligations for states not to cause any disappearance) is considered by many to be one of these universally accepted norms. The right to truth has until recently hardly been expressed in treaties, but the obligation to provide information to relatives of a disappeared person is considered a norm of customary law. States are expected to inform families about the fate and whereabouts of a disappeared person. Some instruments contain norms that create obligations to address the humanitarian dimension of enforced disappearances. Some focus merely on ensuring that criminals are brought to justice (the criminal dimension). Human rights instruments contain norms relevant to the responsibility of the State (the human rights violation) but also to the other dimensions. Some of these agreements/instruments contain hard commitments, which can be claimed in front of a court and are called legally binding norms. This is the case for instruments with names as treaties, conventions, covenants and statutes. Some other instruments also contain obligations, but set as non-binding norms (declarations, guidelines or sets of principles for instance). Non binding means that a State cannot be forced to comply with these norms. Lawyers often refer to them as soft law. When these instruments are adopted, countries are expected to uphold these agreements but cannot be held accountable if they do not. Non-binding instruments still have a significant moral and symbolic value and contribute to setting relevant standards in international law. The acceptance of a norm by a state creates an obligation for that state to respect, protect, and fulfill that norm. This often means taking concrete measures. Taking these concrete measures is what is called the implementation of a norm. In relation to enforced disappearances concrete measures include: opening investigations; adopting laws that make prosecution possible; striking down laws that cause impunity of persons who have committed disappearances; taking measures of reparation (like paying compensations to victims, or to recognise responsibility for disappearances publicly); providing training on and education about disappearances to soldiers and policemen; taking preventive measures (like keeping centralised and updated registers of prisoners. International instruments and mechanisms are tools (or weapons) in the legal struggle against enforced disappearances. International norms, instruments or 
mechanisms are not accepted to the same extent in every country, which means that there is no single system for confronting disappearances. As a result, each country has its own 'mix' of norms and mechanisms, which victims and civil society organisations can use to confront enforced disappearances.

The right for individuals to know the truth about the fate of disappeared persons or information about other past abuses has been affirmed in treaties, regional courts, and international and domestic tribunals. A truth commission reaches out to thousands of victims in an attempt to understand the extent and the patterns of past violations, as well as their causes and consequences. Reconciliation is understood differently in different contexts. For some, the full acknowledgement of a long denied truth will certainly advance reconciliation. But experience shows that many individual victims and communities may require more than the truth in order to forgive. 35

At the invitation of the Government of Bosnia and Herzegovina, the UNWGEID visited the country from 14 to 21 June 2010. The main recommendations of the Working Group include setting up the Central Records of Missing Persons and the Fund for Support to the Families of Missing Persons, as provided for in the law on missing persons. More support should be given to the work of the Missing Persons Institute and for prosecutors working on exhumations and war crimes prosecutions. A national program on reparations for relatives of victims of enforced disappearance should be established and protection and assistance programs for victims and witnesses should be strengthened. ${ }^{36}$

35 U.N. Office of the High commissioner for Human Rights, Rule-Of-Law Tools For Post-Conflict States: Truth commissions, HR/PUB/06/1 (2006), available at http://http://www.ohchr.org/Documents/ Publications/ RuleoflawTruthCommissionsen.pdf (last visited Feb. 3, 2013).

36 U.N. Office of the High commissioner for Human Rights, Working Group on Enforced or Involuntary Disappearances, http://www.ohchr.org/ EN/ Issues/Disappearances/Pages/DisappearancesIndex.aspx (last visited Feb. 3, 2013). 


\section{Conclusion}

A person that causes another person to disappear is guilty of a crime and may be held personally and individually responsible for that crime. It is important to notice that an enforced disappearance is in fact constituted by a combination of two actions or behaviours: the 'deprivation of liberty' and 'the denial or concealment of information of elements'. It is today internationally agreed that enforced disappearances when committed on a massive and systematic scale, as usually happens in the armed conflicts, can qualify as a crime against humanity, to which several jurisdictions and sanctions apply.

Development of effective rehabilitation approaches and programs for victims must necessarily continue in order to minimize the horrifying and lasting effects of forced disappearance. Justice denied is a persistent irritant to the psychological wounds of victims, and obtaining justice for the survivor holds paramount significance. Besides paying for the physical and moral harm suffered by the victims as a result of the violation, compensation also entails measures to repay any damage that can be assessed in economical terms, for instance, lost opportunities (including employment or social benefits), material damage or loss of earnings, costs of legal counsel, medical and other costs generated. Satisfaction is another form of non monetary measure that aims to restore the dignity and reputation of the disappeared persons and their relatives. In some cases, satisfaction can be obtained by a judgment condemning the disappearance. Guarantees for non repetition of such crime to ensure that the enforced disappearances do not reoccur in the future may include - the duty to adopt legislation protecting people from disappearances, ensuring the control of military forces by civilian officials, guaranteeing the independence of judges, protecting those groups who are especially at risk of being disappeared, removing personnel that have been involved in disappearances from official positions, proper training for security personnel and members of the armed forces, etc. The prevention of the human rights abuse within the framework of the progressive movement in essence will also require a social change. 